\author{
Natalia Ananiewa \\ Uniwersytet Moskiewski imienia Łomonosowa \\ Katedra Filologii Słowiańskiej Wydziału Filologicznego \\ ORCID: 0000-0003-1626-2243; e-mail: ananeva.46@mail.ru
}

\title{
Słownictwo polskie w gwarach rosyjskich (na podstawie materiałów Словаря русских народных говоров)
}

\begin{abstract}
Abstrakt: Na podstawie materiałów pierwszych tomów Słownika rosyjskich gwar ludowych w artykule dokonano analizy rosyjskiego słownictwa gwarowego, które prawdopodobnie powstało na skutek oddziaływania języka polskiego. Główne uzasadnienie kwalifikacji rosyjkiego wyrazu gwarowego jako ewentualnej pożyczki z polszczyzny stanowi jego lokalizacja: Smoleńszczyzna, Litwa, Łotwa i niektóre inne regiony. Analizowane są poszczególne części mowy i klasy leksykalno-semantyczne wyrazów samodzielnych.
\end{abstract}

Słowa kluczowe: język rosyjski, język polski, gwara, słownictwo, pożyczka, lokalizacja.

\begin{abstract}
Polish vocabulary in Russian dialects (based on the materials from the Dictionary of the Russian Folk Dialects). With reference to the materials of the first volumes of the Dictionary of the Russian Folk Dialects, the article analyses the vocabulary of Russian dialects which was probably originated by Polish words. The main principle behind qualifying a Russian dialectal word as a borrowing from Polish is its location: the region of Smolensk and its surroundings, the territories of Lithuania and Latvia and some other areas. Different parts of speech and lexical and semantic classes of independent words are considered.
\end{abstract}

Keywords: Russian, Polish, dialect, vocabulary, borrowing, location.

Problematykę wpływów polszczyzny na język rosyjski w wiekach XV-XVIII, a nawet w okresie wcześniejszym niejednokrotnie poruszali zarówno badacze polscy, jak i rosyjscy (Kochman 1967; 1975; Милейковская 1984; Witkowski 2000; 2018; Шетеля 2008; 2011 i in.). Zauważono, że polonizmy występują nie tylko w rosyjskiej odmianie literackiej, lecz również w gwarach rosyjskich, w tym nawet w okolicach Moskwy (Wójtowicz 2018, 553-564). Oczywiście chodzi tu nie o wspólne dziedzictwo z prasłowiańszczyzny, a o słownictwo powstałe w gwarach rosyjskich na skutek oddziaływania na nie żywiołu polskiego (bezpośrednio lub poprzez pośrednictwo białoruskie bądź ukraińskie, czyli te języki, które w swoim czasie wchłonęły dużą dawkę polszczyzny).

Zadaniem niniejszego artykułu jest przedstawienie materiału gwar rosyjskich zaczerpniętego głównie z pierwszych tomów Словаря русских народных говоров (СРHГ, Słownik rosyjskich gwar ludowych), który można ewentualnie uważać za przejaw wpływu polszczyzny. Główną zasadą, na podstawie której określamy leksem 
jako ewentualny polonizm, jest jego lokalizacja (kwalifikatory lokalizacyjne w СРНГ):

- Kwalifikatory lokalizacyjne wskazujące na występowanie wyrazu jedynie w gwarach rosyjskich na obszarze Litwy, Łotwy, rzadziej Estonii („Йонав. Лит. ССР, Прейл. Латв. ССР, Йыгев Тарт. Эст."). Funkcjonowanie tych ewentualnych polonizmów wyłącznie na terenie republik nadbałtyckich na tle braku przykładów z innych części rosyjskiego kontinuum gwarowego świadczy o powstaniu tych wyrazów pod wpływem polszczyzny, której użytkownicy na tych terenach od dawna znajdowali się w stałych kontaktach z nosicielami gwar rosyjskich.

- Kwalifikatory lokalizacyjne wskazujące na Smoleńszczyznę (Смол.) - strefę przejściowych gwar rosyjsko-białoruskich historycznie związaną z Rzecząpospolitą - albo jako jedyne, albo obok wyżej wymienionych. Większość wyrazów wspólnych dla języka polskiego i białoruskiego ma rodowód polski. To samo można powiedzieć także o języku ukraińskim. Chociaż i w polszczyźnie znajdujemy dużo rutenizmów (np. czub, czupryna, osetedec). Język białoruski na tym obszarze mógł zatem przyczynić się do rozpowszechnienia polonizmu, odegrać rolę pośrednika. Okresowa przynależność tego terytorium do państwa polskiego wzmacniała oddziaływanie polszczyzny na gwary smoleńskie.

- Kwalifikatory lokalizacyjne „zachodni” (Зап.) albo „południowy” (Южн.) jako jedyne w Słowniku Włodzimierza Dala, którego materiały były wykorzystane w СРНГ. W pierwszym wypadku (Зап.) wyraz mógł być albo bezpośrednią pożyczką z polskiego albo wejść do gwary rosyjskiej za pośrednictwem języka białoruskiego. W drugim (Южн.) rolę takiego pośrednika mógł odegrać język ukraiński. Przypuszczam, że podobne jest pochodzenie odpowiedników polskich z kwalifikatorami lokalizacyjnymi w guberniach woroneskiej (Bорон., dziś obwód woroneski) i tambowskiej (Тамб., dziś obwód Tambowski).

Oprócz wymienionych obszarów często wyrazy analogiczne do leksemów polskich występują również w gwarach pskowskich i archangielskich (zjawisko częstej zbieżności materiału gwar archangielskich ze słownictwem polszczyzny potwierdza kierowniczka Pracowni Słownika Gwar Archangielskich Wydziału Filologii Uniwersytetu Moskiewskiego prof. Jelena Niefiedowa). Przyczyny powstania takich odpowiedników mogą być różne. Możliwe jest, że niektóre z nich należą do tak zwanych izoglos północnosłowiańskich. Dla gwar pskowskich, przynajmniej w tej ich części, którą badacze gwar rosyjskich określają jako wywodzącą się z białoruszczyzny, możliwe jest takie samo thumaczenie występowania polonizmów jak dla gwar Smoleńszczyzny.

Wychodząc ze sformułowanych tu założeń, przejrzałam materiał niektórych tomów СРНГ, głównie pierwszych. Już początkowe stadium badań pozwala na stwierdzenie występowania słownictwa o rodowodzie polskim bądź nawiązującego do polszczyzny, z jednej strony należącego do różnych części mowy, a z drugiej - do różnych klas leksykalno-semantycznych (przede wszystkim w obrębie rzeczowników i czasowników).

Przynależność do określonych klas leksykalno-gramatycznych lokuje domniemane pożyczki przede wszystkim wśród rzeczowników, czasowników i przymiotników. Zanotowano także przysłówki, spójniki i nawet wykrzykniki. Rzuca się w oczy 
niekonsekwentne podawanie ekwiwalentów polskich, np. dla rzeczowników альтана, брама, аркуш, варта, агрест takie odpowiedniki są przytoczone. Natomiast dla szóstego znaczenia czasownika nравиmь ('mówić, 'opowiadać'), dla którego podany jest tylko jeden przykład użycia w gwarze rosyjskiej powiatu jonawskiego na Litwie - byłej Litewskiej Socjalistycznej Republice Radzieckiej (skrót w СРНГ - Лит. CCP), dla rzeczownika властитель ('gospodarz'), który też jest zapisany w gwarach nadbałtyckich, dla czasownika вендить (przykład z Litwy) oraz dla adresatywów васnан i васпани (zapisy z powiatu jonawskiego na Litwie i z gwar smoleńskich) takich odpowiedników w СРНГ nie ma. W dalszej części tekstu podaję hasła słownikowe w ten sam sposób, w jaki one są przedstawione w СРНГ, czyli używam języka rosyjskiego dla wyrazu gwarowego, jego odpowiednika w rosyjskiej odmianie literackiej i kwalifikatora lokalizacyjnego.

Wśród rzeczowników występują następujące klasy leksykalno-semantyczne:

\section{- Osoby i zbiór osób}

Przykłady:

Банкарт. 'Незаконнорожденный ребенок'. Йонав. Лит. ССР 1963 (СРНГ II 1966, 94). Polski bękart (z niem. Bankart). Poszerzona samogłoska (a na miejscu pol. e) w pierwszej sylabie świadczy o tym, że ten wyraz znalazł się w gwarze rosyjskiej na Litwie jako pożyczka z miejscowych gwar polskich, których cechą charakterystyczną jest tak zwane akanie na miejscu ogólnopolskiego $e$ (w tym na miejscu nosówki e): por. gwar. ida f ta strona, stołam, nasza ojcy - liter. Idę w tę stronę, stołem, nasi ojcowie. Lokalizacja leksemu nie pozwala na przypuszczenie bezpośredniego zapożyczenia z niemieckiego Bankart.

Блазен/Блазень. 1. 'Шалун, баловень'. 2. 'Человек, любящий шутить'. Смол., Пск., Южн. Зап. Даль. Polskim odpowiednikiem i jednocześnie ewentualnym źródłem jest błazen. Nieprzypadkowo pochodny od блазен wyraz блазенство w znaczeniu ros. 'шутовство, балагурство, повесничанье' podany jest w słowniku Włodzimierza Dala z kwalifikatorem lokalizacyjnym Зап. i właśnie z taką lokalizacją został przeniesiony do СРНГ (II 1966, 313).

Варта. 'Караул, стража'. Смол. Смол. 1902-1904.: Как выгоняют с понеделку. Держат до субботы. А в субботу на работу. А в воскресенье на варту. Смол. Добровольский (СРНГ IV 1969,60). W przytoczonym kontekście wyraz варта występuje w znaczeniu 'pewien rodzaj służby wykonywany przez jedną osobę lub przez szereg osób’. W СРНГ podane jest polskie źródło.

Васnан, Васпаня i pochodne od nich adresatywy. Васnан występuje w funkcji grzecznego zwracania się do osoby płci męskiej (ros. 'господин, сударь'): Kyдbl mbl идешь, васпан? Смол. Смол. 1919-1934; Васnан - вы (ironicznie) Йонав. Лит. CCP ( СРНГ IV 1969, 66). Zdrobnienie васпаник w formie wołacza: Потерпи, васпанику мой! Смол. Смол. 1919-1934 (СРНГ IV 1969, 67). Васпаня występuje w funkcji grzecznego zwracania się do osoby płci żeńskiej (ros. госпожа, сударыня). Adresatywy васпан і васпаня powstały z polskich zwrotów waszmość pan, waszmość pani, które przekształciły się w wasan, wasani i wasanna (z waszmość panna). Z kolei waszmość jest uniwerbem od zwrotu wasza miłość. W СРНГ, jak już zasygnalizowałam, zabrakło polskich odpowiedników. 
Властитель. 'Хозяин. владелец, владетель': Властитель дому своему и хозяйству. Йонав Лит. ССР 1963. Теперика никто не властитель ни над кем, ни над чем. Прейл. Латв. ССР. А ты какой-такой властитель мне приходишься Йыгев. Тарт. Эст. ССР (СРНГ IV 1969, 318). Brakuje polskiego odpowiednika/źródła właściciel.

\section{- Świat roślinny}

Przykłady :

Аграст/Агрест. 'Крыжовник.' Forma z $a$ w drugiej sylabie występuje w przykładzie zapisanym w gwarze rosyjskiej funkcjonującej na obszarze Litwy, czyli mamy tu do czynienia z tym samym zjawiskiem fonetycznym co w wyrazie банкарт. Аграст зеленый ядут (СРНГ I 1965, 202). Wariant агрест zarejestrowany jest na Smoleńszczyźnie i w gwarze na terenie Łotwy: Агресm ядут подуростки, я их за каршень. Ноньч ахрест такой не пошльий (СРНГ I 1965, 202). W słowniku Dala przytoczony wyraz występuje z kwalifikatorem lokalizującym Южн., co wskazuje na ewentualne bezpośrednie źródło ukraińskie. Z kolei do języka ukraińskiego ten leksem na pewno przedostał się z polszczyzny.

Do wyrazu azpacm/arpecm w CРНГ podany jest odpowiednik polski i wskazane jest źródło tego wyrazu w polszczyźnie (nowołacińskie agrestia, włoskie agresto).

Баня. 'Тыква' (Зап. u Dala; СРНГ II 1966, 93).

Блаватка. 'Василек'. Przynależność do polonizmów tego wyrazu jest względna: jeżeli kwalifikator Петерб. (od nazwy miasta Petersburg) u Dala, biorąc pod uwagę dużą liczbę polskiej ludności w dziewiętnastowiecznym Petersburgu, może w pewnym sensie świadczyć o polskim rodowodzie leksemu, to występowanie tego wyrazu w guberni jarosławskiej (kwalifikator Яросл.) jest trudne do wyjaśnienia. Chociaż odnalezienie polonizmów w gwarach rosyjskich aż pod Moskwą i tłumaczenie tego zjawiska jako śladu dawniejszych wpływów polszczyzny na język rosyjski w różnych jego odmianach może rzucić światło na tę kwestię. W CPHГ przytoczony jest odpowiednik ukraiński: блават (prawdopodobne źródło w ukraińskim stanowi pol. bławat, bławatek, którego zabrakło w СРНГ; w języku ukraińskim rozpowszechniona jest inna nazwa tego kwiatu - волошки).

Брусквиня. 'Персик' (kwalifikator Южн. u Dala). Por. pol. brzoskwinia. Aleksander Brückner uważa wcześniejsze brzoskiew, brzoskinia i brzeskinia za zachodniosłowiańskie pożyczki z niemieckiego, do którego ten wyraz przedostał się z łaciny (Brückner 1970, 45).

\section{- Świat zwierzęcy}

Przykłady :

Бомка/Бонка. 3. 'Овод, слепень' (pol. 'giez'): Бонки - большие слепни, больше пчел, очень больно кусаются. Йонав. Лит. ССР 1963; Бонки, как пчель, большие. Прейл. Латв. ССР ( СРНГ III 1968, 95). Leksem występuje w gwarach polskich na terenie Litwy i odpowiada pol. bąk (ros. слепень, овод ).

Вевёрка. 'Белка'. Зап. Даль (СРНГ IV 1969, 89). Ten sam model słowotwórczy mamy w pol. wiewiórka (ros. белка).

Dla pskowskiego leksemu ботян ('аист’) poprzestaję na stwierdzeniu obecności jego odpowiednika w polszczyźnie (bocian). 


\section{- Odzież}

Przykład:

Ватувка. То sато со ватовка: На вате такая одежда сделана, называют ватувка. Йонав. Лит. ССР 1963 (СРНГ IV 1969, 73) W СРНГ podane jest polskie źródło - watówka (ros. ватник; телогрейка).

\section{- Potrawy}

Przykład :

Бикус. 'Окрошка'. То же Пикус. Зап. Даль (СРНГ II 1966, 305). Przytoczony jest polski odpowiednik/źródło bigos (ros. род мясной солянки, бигос). W polszczyźnie należy do germanizmów.

\section{- Naczynia}

Przykład:

Бляха. Oznacza i materiał - ros. жесть, i naczynia z tego materiału - brytfannę oraz przedmiot podobny do dzbana z kurkiem. Większość przykładów pochodzi $\mathrm{z}$ powiatu jonawskiego na Litwie, jest przykład $\mathrm{z}$ Łotwy, a jeden kwalifikator lokalizacyjny wskazuje na gwarę pskowską. Przykłady kontekstów: znaczenie 'materiał' - Ну на что эта бляха, бросай. Прейл. Латв. ССР. Крыши бывают с соломы,гонmy, бляхи. Йонав. Лит. СCP; znaczenie 'brytfanna' - Насадили целую бляху булок Йонав. Лит. CСР 1963; znaczenie 'naczynie' ('жестяная посуда с краном, похожая на бидон, в который ставят молоко в холодную воду для отстаивания сливок') Кто-то опять бляху с молоком в ключ впустил. Йонав. Лит. ССР 1963 (СРНГ ІІІ 1968, 34). W tej samej rosyjskiej gwarze na Litwie w znaczeniu 'naczynie' występuje także leksem бляшанка. Por. pol. blacha, blacharz, blaszanka wywodzące się z niem. Blech. Za pośrednictwem polszczyzny ten germanizm rozpowszechnił się na Rusi (Brückner 1970, 28). W СРНГ z kwalifikatorem Зап. według Dala podana jest nazwa garnka, który składa się z dwu części: близнятьл/близнята. Nasuwa się tu analogia do pol. bliźniaki (oraz gwarowego dwojniaki).

\section{- Budowle (w tym nawierzchnie dróg), części budowli, materiał budowlany}

Przykłady:

Альтана. 'Беседка'. Зап. Даль. Podany jest polski odpowiednik altana (z włoskiego) (СРНГ I 1965,246).

Брама. 'Крепостные, монастырские и т.п. ворота'. Смол. Даль. 'Ворота'. Йонав. Лит. ССР 1961 (СРНГ III 1968, 148). Podany jest polski odpowiednik/źródło brama (ros. ворота).

Брук. 1. 'Булыжная мостовая'. Йонав. Лит. ССР 1961 (СРНГ III 1968, 201). W СРНГ przytoczony jest polski odpowiednik - bezpośrednie źródło bruk. W drugim znaczeniu - 'mielizna' występuje na Smoleńszczyźnie.

Будынок. Будинок. 'Небольшое каменное здание'. Южн. Зап. Даль; будынок 'постройка, здание'. Тута в лесу стоит будынок. Смол. 1919-1934. W СРНГ podane są odpowiedniki z języka ukraińskiego i białoruskiego (ukr. будинок, białoruski будынок), jednak nie ma odpowiednika polskiego budynek, który na pewno był źródłem dla tych wyrazów w ukraińskim i białoruskim. Tu jeszcze raz możemy 
podkreślić pewną niekonsekwencję w przytaczaniu odpowiedników polskich $\mathrm{w}$ СРНГ: dla czasownika будовать mamy taki odpowiednik (,укр. будувати из польск. budować"), a dla rzeczownika будынок/будинок zabrakło analogicznego wyrazu polskiego. W СРНГ podane są również różne formacje modyfikacyjne z pierwiastkiem буд-, które występują w gwarach smoleńskich i w gwarze rosyjskiej na terenie Litwy: будыночек Смол. 1902-1904, будыня і будынина Смол. 1914, будынка Йонав. Лит. CCP 1961 i in. (СРНГ III 1968, 248).

Вапна. 'Известь, известка'. Новорос. Даль. Тута, на берегу Днепра, добывают вапну. Смол. Вапной печки и стены белят. В этой яме вапны не было. Йонав. Лит. ССР. Надо достать вапну - побелить печку. Прейл. Латв. ССР. Kwalifikator lokalizacyjny Новорос. u Dala nie przeczy przypuszczeniu o polskim wapno (wapień) jako źródle leksemu вапна, ponieważ Новорос. (czyli południowe) mogło powstać pod wpływem języka ukraińskiego, w którym (tak samo jak w białoruszczyźnie) ten wyraz pochodzi z polskiego. Zresztą pierwiastek wap- 'farba' nawiązuje do prasłowiańszczyzny, wyraz wapa w znaczeniu 'bagno' znany jest językowi słoweńskiemu i występuje w Rękopisie Supraskim (Brückner 1970, 61; Старосл. слов. 1994, 108).

Свирна. 1. 'Амбар'. У поляков свирна. Себеж. Великолукск. 1959; Зерно храним в свирне. Даль (СРНГ III6 2002, 295). Poza tym u Dala z kwalifikatorem lokalizacyjnym зап. podane są warianty свирон і свирень ('амбар, житница'), których zabrakło w СРНГ ( Даль IY 1955, 150). Por. pol. świron (ros. амбар).

\section{- Przedsiębiorstwa}

Przykład:

Бровар 1. 'Винокуренный завод'. Йонав. Лит. ССР 1961 (w tej samej gwarze występuje w znaczeniu 'przyrząd do pędzenia bimbru') obok wyrazu броварня 1. 'Пивоваренный завод’. Зап. Даль (drugie znaczenie z tą samą lokalizacją: 2. 'Meдоваренный завод').

Броварь то же, что бровар. Смол. 1835 (СРНГ III 1968, 183). W CРНГ przytacza się niem. Brauer, ale brak pol. browar, stanowiącego bezpośrednie źródło odpowiedniego rosyjskiego wyrazu gwarowego.

\section{- Przedmioty użytku domowego, narzędzia godpodarcze, przyrządy}

Арфа. 'Решето, грохот'. Когда арфы не было, весякам зерняты сеяли. Йонав. Лит. CCP 1963; por. pol. arfa i ros. 1. 'грохот (решето)', 2. 'сортировка, веялка' (młynek do wiania zboża).

Бизун. 'Плеть, кнут, хлыст'. Пск. Ворон. Даль (z kwalifikatorem польск.), Смол. Отлупили как следует бизуном. А бизуна не хочешь? Йонав. Лит. ССР. Бизун это кнут. Бизун поляки говорят. Прейл. Латв. ССР 1963. 'Кнут, плеть, жгут, сделанный из узкого полотенца'. Смол. 1919-1934. 'Наказание плетью, хворостиной’. Дай ему бизуна. Пск. Ворон. Даль, por. pol. bizun (odpowiednik czy źródło?).

Бэмбен. 'Барабан конной молотилки'. Йонав. Лит. ССР (СРНГ III 1968, 358), por. pol. bęben, odpowiadający ros. барабан w wielu znaczeniach, w tym i w znaczeniu technicznym, w którym występuje przytoczony wyraz gwarowy - bęben młockarni (ros. барабан молотилки). 
Вага. 'Весы'. Przykład pochodzi z gwary rosyjskiej na Łotwie (Садись здесь на вагу Саня), por. pol. waga (ros. весы; вес). Do polszczyzny weszło z języka niemieckiego (Wage), a z ziem polskich rozpowszechniło się w językach wschodniosłowiańskich: jak pisze Brückner, „od nas na całą Ruś przeszło” (Brückner 1970, 598).

- Przejaw działań fizycznych

Przykład:

Буся. 'Поцелуй'. Дать бусю поиеловать. Красл. Смол. 1914. Бусяк 1. 'Поцелуй'. Смол. (СРНГ III 1968, 308), por. wyraz polski z dźwięcznym ź: buzia (ros. ротик, личико; dać buzi ros. почеловать).

\section{- Jednostki administracyjne}

Przykład:

Вёска. 'Деревня, деревенька' (СРНГ IV 1969, 183). Możliwy jest wpływ polskiego modelu słowotwórczego - wioska (ros. деревня, деревенька).

- Zjawiska natury

Przykład :

Ветрик. 'Ветерок'. Славный сегодня ветрик. Смол. 1918-1934 (СРНГ IV 1969, 292), por. ten sam model słowotwórczy w pol. wietrzyk (ros. ветерок).

Wśród czasowników wyodrębniły się następujące klasy leksykalno-semantyczne:

\section{- Przygotowanie jedzenia}

Przykład:

Вендить. 'Коптить что-либо': Вендить сало, колбасу. Йонав. Лит. ССР 1961. Вендить мясо, колбасы, кумпаки. Мясо вендят вересом. Вересом сало можно вендить. Лит. ССР (СРНГ IV 1969, 111), por. pol. wędzić (ros. коптить).

\section{- Stawianie oporu}

Przykład:

Вальчиться. 3. 'Бороться', a także ‘драться' (pol. bić się), 'судиться' (pol. procesować się), występujące na tym samym terenie Smoleńszczyzny - Смол.1914 (СРНГ IV 1969, 33), por. polski odpowiednik/źródło walczyć (ros. бороться, сражаться, воевать).

\section{- Ochrona czegoś lub kogoś}

Przykład :

Вартовать. 'Сторожить, охранять': Кто ночью вартовал коней. Смол. 19191934 (СРНГ IV 1969, 60). Polski odpowiednik podano w błędnej formie: watrować zamiast wartować.

\section{- Działania kreatywne}

Przykład:

Будовать. 'Строить'. Зап. Южн. Даль: Колядки настают. Детки терем будуюm с трема окнами. Красн. Смол.1914, Йонав. Лит. ССР (СРНГ III 1968, 245). 
Podane są odpowiednik ukraiński i jego bezpośrednie źródło polskie: будувати, budować.

\section{- Dzialania destrukcyjne}

Przykłady :

Брукать. 'Пачкать, гадить'. Зап. Даль (2-е изд.) (СРНГ III 1968, 201). Przytoczone jest odpowiednie polskie źródło brukać (ros. пачкать, марать).

Сбанкрутовать. 'Обанкротиться': Он скоро сбанкрутовал, всю скотину распродал, затем землю продал. Йонав. Лит. ССР 1960 (СРНГ XXXVI 2002, 163). Brak polskiego odpowiedniego wyrazu zbankrutować. W rosyjskim języku literackim występował polonizm банкруm (wywodzący się z włos. bancarotta), który z biegiem lat zmienił swoje oblicze fonetyczne: $\mathrm{w}$ drugiej sylabie zamiast pierwotnego $u$ pojawiła się samogłoska $о$ - банкрот. W СРНГ zarejestrowany jest także wyraz банкрутина w znaczeniu 'oszust' (ros. плуm): Ворон. Смол. 1850 (СРНГ II 1968, 95).

Сбутветь. Сопреть, истлеть, сгнить: Картошка сбутвела. Лит. ССР 1960 (СРНГ XXXVI, 2002, 196). Brak w СРНГ pol. zbutwieć (ros. conpemь, истлеть, прогнить).

\section{- Mówienie}

Przykład:

Править. 'Говорить, рассказывать': Любит байки править Йонав Лит. ССР (СРНГ ХХXI 1997, 57). W СРНГ zabrakło polskiego odpowiednika prawić (ros. говорить, рассуждать, рассказывать).

\section{- Ruch}

Przykład:

Блондать. 'Блуждать': Скрозь день блондала по лесу, грибов искала. Где ть блондаешь без меня? Йыгев. Тарт. Эст. ССР 1963 (СРНГ III 1968, 27). W СРНГ brak polskiego odpowiednika błądzić (ros. блуждать).

Przykłady przymiotników i przysłówków z СРНГ, którym odpowiadają identyczne lub podobne wyrazy polskie:

Безмаетный. 'Беспоместный' (dawniej о obszarniku bądź dziedzicu). Зап. Даль (СРНГ II 1966, 192). Por. pol. majętny (ros. зажиточный, состоятельный, богатый).

Бляманный. Йонав. Лит. ССР, Прейл. Латв. ССР (о wyrazach бляха, блямка јuż pisałam), por. pol. blaszany (ros. жестяной).

Бридкий. 'Противный' - «вдоль западной границы РСФСР», Русская диалектология. Бридной - 'гадкий, отвратительный'. Соседние с Украиной губернии Даль. Бридный. Смол. 1914 (СРНГ III 1968, 179), por. pol. brzydki (brak w СРНГ). W СРНГ jest także przysłówek бридко i nie ma jego polskiego odpowiednika brzydko.

Брудный. 'Грязный, мутный'. Смол. 1914. Текет река, мутна - брудна, нельзя воды пити (песня) Смол. Добровольский, Йонав. Лит. ССР (СРНГ III 1968, 200). W СРНГ zabrakło odpowiednika polskiego brudny. Jeśli chodzi o rzeczownik бруд, który również jest znany językowi polskiemu (brud - ros. грязь), to jego zasięg wystę- 
powania jest szerszy: oprócz kwalifikatorów lokalizacyjnych Йонав. Лит. ССР, Смол. (por. przykład ze Smoleńszczyzny: По речке пойшел бруд), Зап. і Южн. według Dala, Пск., mamy dla tego wyrazu kwalifikatory Орл., Курск. (СРНГ III 1968, 200).

Властный. 'Собственный': Подписал рукою властною. Зап. Даль. (СРНГ IV 1969, 318) W SRGL brak odpowiednika polskiego własny (ros. собственный).

Z wyrazów niesamodzielnych, mających odpowiedniki polskie, w CРНГ występuje spójnik але/али (w piątym z przytoczonych w СРНГ siedmiu znaczeń - ros. 'но'). Przykłady pochodzą $\mathrm{z}$ rosyjskich gwar Litwy i Łotwy, nр.: Деньги в кассу не складаем, али без денег не живем. И его хотели втянуть в свою компанию, али он был хитрей. Лит. ССР (СРНГ I 1965, 237).

Mamy w СРНГ także wykrzyknik бодаŭ, dla którego podane są polskie odpowiedniki bogdai i bodai (z $i$ w wygłosie zamiast $j$ ). Kwalifikatory lokalizacyjne: nie tylko Смол., lecz także Ворон. і Тамб. (СРНГ III 1968, 47). Z językiem polskim kojarzy się również występowanie nagłosowego $a \mathrm{w}$ wykrzykniku używanym na Smoleńszczyźnie dla odpędzania ptactwa domowego - aкblu! (ros. kblu!), por. pol. apsik! (ros. брысь!), a kysz! (ros. кbıш!). Ostatni wyraz występuje w gwarach polskich na Białorusi i Litwie.

Badania materiałów СРНГ, które mają na celu odnalezienie w rosyjskim słownictwie gwarowym odpowiedników polskich, znajdują się dopiero w stadium początkowym. Po analizie wszystkich tomów СРНГ, które ukazały się w druku, możliwe będzie w przybliżeniu (bo wydanie СРНГ jeszcze nie jest doprowadzone do końca) ustalenie tego, jaki procent w systemie leksykalnym gwarowej odmiany języka rosyjskiego stanowią wyrazy kojarzące się z polszczyzną.

\section{Literatura}

Brükner A. (1970), Stownik etymologiczny języka polskiego, Warszawa.

Kochman S. (1967), Polsko-rosyjskie kontakty językowe z zakresu stownictwa w XVI-XVII w., Wrocław-Warszawa-Kraków.

Kochman S. (1975), Polsko-rosyjskie stosunki językowe od XVI do XVIII w. Stownictwo, Wrocław.

Witkowski W. (2018), O polonizmach w języku rosyjskim raz jeszcze, [w:] „Rozprawy Komisji Językowej”, t. LXVI, Łódź, s. 531-552.

Witkowski W. (2020), Zapożyczenia z polskiego w rosyjskiej terminologii medycznej, [w:] Kontakty językowe polszczyzny na pograniczu wschodnim, red. E. Wolnicz-Pawłowska, W. Szulowska, Warszawa, s. 273-279.

Wójtowicz M. (2018), O zapożyczeniach polskich w stownictwie gwar okolic Moskwy, [w:] Rozprawy Komisji Językowej, Tom LXVI, Łódź, s. 553-564.

Даль В. [Dal' V.] (1955) Толковый словарь живого великорусского языка [Tolkovyi slovar' zhivogo velikorusskogo iazyka], t. IV, Москва [Moskva].

Милейковская Г. [Mileikovskaia G.] (1984), Польские заимствования в русском литературном языке $X V$-XVIII веков [Polskie zaimstvovaniia v russkom literaturnom iazyke $X V$-XVIII vekov], Warszawa. 
СРНГ [SRNG], Словарь русских народных говоров [Slovar russkih narodnykh govorov], Moсква-Ленинград-Санкт-Петербург 1965-.

Старославянский словарь (по рукописям X-XI веков) [Staroslovianskii slovar (po rukopisiam $X-X I$ vekov], ред. Р.М. Цейтлин, Р. Вечерка и Э. Благова [R.M. Tseĭtlin, R. Vecherka, E். Blagova], Москва 1994.

Шетеля В. М. [Shetelia V.M.] (2008), Историко-этимологический словарь полонизмов русских текстов XIX-XX в.в. [Istoriko-etimologicheskii slovar polonizmov russkikh tekstov $X I X-X X$ v.v.], Москва.

Шетеля В. [Shetelia V.] (2011), О польских заимствованиях в русской литературной речи XIX в. [O pol'skikh zaimstvovaniiäkh v russkol literaturnol̆ rechi XIX v.], [w:] Русско-польские языковые, литературные и культурные контакты [Russko-polskie iazykovye, literaturnye i kulturnye kontakty], Москва, s. 25-31. 